\title{
Mass Antibody Detection: Can It be An Avenger for Infectivity War against COVID-19
}

Sarfaraz Ahmad Ejazi, Sneha Ghosh, Nahid Ali ${ }^{*}$

Affiliation:

Infectious Diseases and Immunology Division,

CSIR-Indian Institute of Chemical Biology,

4 Raja S C Mullick Road, Jadavpur, Kolkata, West Bengal, India.

${ }^{*}$ Correspondence:

Professor Nahid Ali

nali@iicb.res.in, nahidali28@yahoo.in

Telephone number: +91332499 5757;

Fax no: +913324735197

Keywords: COVID-19; diagnosis; ELISA; RDT; point-of-care test; antibody; proteins 


\section{Abstract}

The ongoing pandemic of COVID-19 has not only commenced a global health emergency but agitated various aspects of humanity. During this period of crisis researchers over the world have ramped their efforts to constrain the disease in all possible ways whether it is vaccination, therapy, or diagnosis. Since the spread of the disease has not yet elapsed sharing the ongoing research findings could be the key to disease control and management. An early and efficient diagnosis could leverage the outcome until a successful vaccine is developed. Molecular tests both in-house and commercial kits are preferably being used worldwide in the COVID-19 diagnosis. However, the limitation of high prices and lengthy procedures impede their use for mass testing. Keeping the constant rise of infection in mind search for an alternative test that should be cost-effective, simple, and suitable for large scale testing and surveillance is a need of an hour. One such alternative could be the immunological tests. Therefore, in the last few months deluge of immunological rapid tests has been developed and validated across the globe. The objective of the present review is to share the diagnostic performance of various immunological assays reported so far in SARS-CoV2 case detection. The article consolidated the studies (published and preprints) related to the serological tests such as chemiluminescence, enzyme-linked and lateral flowbased point-of-care tests in COVID-19 diagnosis and updated the current scenario. This review will hopefully be an add-on in COVID-19 research and will contribute to congregate the evidence for decision-making. 


\section{What we know about this real-world devil}

The world today has been amalgamated like never before to fight a common enemy to mankind, the pandemic disease namely Coronavirus. Coronaviruses (CoV) belong to the family Coronaviridae responsible for the severe acute respiratory syndrome (SARS) that had first emerged as an epidemic in November 2003. Almost two decades later a novel coronavirus, SARS-CoV-2 originating in Wuhan city of China in December 2019 has led to an unprecedented global pandemic of COVID-19, a serious health challenge that our modern world was yet to see ${ }^{1}$. Despite the same family of viral origin as of SARS, transmissibility and disease severity of COVID-19 are much higher in terms of community spread. As of $31^{\text {st }}$ May 2020, over 6.2 million confirmed COVID-19 cases reported so far with more than 370,000 deaths worldwide ${ }^{2}$ and the numbers are mushrooming by the day. After achieving a plateau in the COVID-19 infection graph in China, a shift in the epicenter of the disease is being seen with the astonishing numbers of new cases and deaths that are being reported in the USA, Iran, and many European countries.

Clinical manifestations of COVID-19 include fever, dry cough, fatigue, and pneumonialike features. The coronavirus is reported to interact with host epithelial cell receptor, angiotensin converting enzyme 2 (ACE2), found in outer surfaces of most of the human body organs leads to endocytosis into the host cell ${ }^{3}$. Severity of the disease occurs when COVID-19 virus (SARS-CoV-2) enters into the lungs through the oral or nasal passage, divides within the lung cells which lead to its death. Dead cells may generate an inflammatory response through IL-6, IL-1, and TNF- $\alpha$ etc., resulting in the consolidation of fluid in the alveolar and interstitial spaces, known as acute respiratory 
distress syndrome (ARDS). The symptomatic clinical condition without ventilation may lead to death due to the insufficiency of oxygen in the vital organs thus multiple organ dysfunctions (kidney injury and cardiac arrest). Chances of this affecting the older age group are more due to their already present comorbidities.

\section{Brief introduction of the current diagnosis}

In the present scenario, while the vaccine is not available for COVID-19 and there is no short and sure treatment, rapid and extensive diagnosis could be the way to reach the grass-root level of the disease and break the widespread chain of this deadly COVID-19 infection ${ }^{4}$. It will have a relevant role in the containment of the disease until a suitable therapy or vaccine strategy is attained. The conventional diagnosis is based on the clinical history and the radiographic findings of the chest but due to the lack of trained individuals in virus imaging and invasiveness of the process, it is routinely practiced only in the initial phase of the epidemic in China. In several areas temporary CT scans have been utilized for clinical diagnosis for false-negative results. These are non-invasive tests, however, was low on specificity, as lung images overlap with any common viral disease. A recent study reported a confirmed case of COVID-19 with no signs of pneumonia in chest CT image ${ }^{3}$. Moreover, CT scans are expensive and constrained in the research labs and big hospitals requiring technical know-how.

From a worldwide perspective, the most popular and gold standard technique which is being used for COVID-19 diagnosis globally is an initial symptomatic analysis followed by molecular-based nucleic acid detection from sputum, nasal and mouth swab and 
serum. The COVID-19 bears a single-stranded RNA genome of approximately 30,000 nucleotides. The nucleic acid testing of COVID-19 is based on reverse transcription polymerase chain reaction (RT-PCR) technique ${ }^{5}$. Several conserved COVID-19 regions have been targeted in the molecular tests such as RNA dependent RNA polymerase gene (RdRP gene), nucleocapsid protein gene ( $\mathrm{N}$ gene), and envelop protein gene ( $\mathrm{E}$ gene). Since this test can amplify even low levels of the virus and detect the disease at an early stage, this has been the most used and reliable detection method. However, the performance of RT-PCR is largely depends on the target viral RNA selected and the primers used. Therefore, the World Health Organization (WHO) time to time published the standard protocol for the parity of the assay. Secondly, variations in the viral load are noticed in different stages of disease manifestations and the biological samples used $^{6}$. Despite a large number of RT-PCR based tests is being conducted throughout the globe its accessibility to reach centers of testing from remote areas restricts its mass appeal. Moreover, they are expensive, equipment-based, time taking, and require developed molecular biology expertise. However, the results are preliminary and most of the in-house PCR tested worldwide have a high false-negative rate in COVID-19 diagnosis ${ }^{7}$. Missed diagnosis of a large number of clinically suspected individuals may promote the spread of the virus that may ultimately lead to faster disease progression. Moreover, in many cases molecular testing often requires more than one test for disease confirmation ${ }^{8}$. RT-PCR is valuable in the initial phase of infection when the virus is present in the body, however, it could not identify the past, recovered, and asymptomatic infections. Most of the countries are under lockdown for almost two months now, it is essential to have a vigorous door to door testing to counter the 
pandemic. Molecular biology-based tests in such cases will become highly cumbersome and should be eased with easier and quicker tests.

Rapid diagnosis to test as much as we can at this point in time may be considered the only hope to fight the disease. As emphasized by the chief of WHO on $16^{\text {th }}$ March just three days after declaring COVID-19 a pandemic to "test, test and test". The Foundation for Innovative New Diagnostics (FIND), Geneva, Switzerland, has published the first result of independent evaluation and clinical performance of five molecular test kits on $16^{\text {th }}$ April. $100 \%$ sensitivity was obtained by all the kits with 50 COVID-19 positive samples and $97-100 \%$ specificity achieved with 100 negative samples ${ }^{9}$. However, there may be asymptomatic or infected patients, who may have cleared the viral load without detection, thus an RT-PCR will fail to test such cases. Therefore, it is important to develop and introduce a rapid and point-of-care test to detect COVID-19 cases and carriers. The antibody-based tests can play an important role in the restraint of COVID19 , facilitate the rapid execution of a control strategy that limits the spread of the disease. The National Health Commission of China in the seventh edition of its novel coronavirus pneumonia diagnosis and treatment plan recently recommended the use of $\lg M / \lg G$ antibodies testing for suspicious cases ${ }^{10}$. Additionally, the convalescent patients will have to be monitored closely for a long-term period, which will involve repeated testing for the presence of antibodies against the disease. For the presence of antibodies, accuracy will be needed, as they will serve as tests of cure. Since most of the countries have permitted the use of antigen or antibody-based serological tests the sensitivity and specificity of these tests against COVID-19 are being reported throughout the world. With the dynamics of the disease changing at the speed of its 
spread, it seems highly essential to get all the information at a glance related to the performance of serological tests reported worldwide to pace our health care needs. This review aims to have a compilation of the performance of various serological assays across the globe for the detection of COVID-19 pandemic.

\section{Key determinants of immunoassay}

Although molecular tests are the gold standard and very specific in early COVID-19 detection its reach to large scale diagnosis is constrained in terms of its cost, feasibility, and rapidness. Immunological assays could be a good complement in this regard. However, concerning diagnosis, immunoassays are different from molecular assays because immunoassays stipulate some knowledge of the protein and the antibody response generated against the protein. Therefore, immunoassays can be engaged to detect either specific viral proteins (antigens) or the antibodies developed by the host B cells in response to that antigen.

The $\sim 30 \mathrm{~kb}$ SARS-CoV-2 genome codes for approximately 27 proteins that include 4 structural proteins, 8 accessory proteins, and 15 nonstructural proteins. The accessory proteins are involved in the replication of viral RNA and transcription. The functions of nonstructural proteins range from replicase, protease, and deubiquitinase, etc. The viral structural proteins comprise of spike glycoproteins (S), membrane glycoproteins (M), envelop proteins $(E)$, and nucleocapsid phosphoproteins $(N){ }^{11}$. The trimeric $S$ protein ( $180 \mathrm{kDa}$ monomer) is postulated to be the first viral fraction to bind with host cell receptors through the receptor-binding domain (RBD) of S1 subunit and helps in the 
fusion of virus and host membranes through $\mathrm{S} 2$ subunit. M protein plays its role in viral morphogenesis and budding through its glycosylated $\mathrm{N}$ terminal domain, three transmembrane domains, and a long $\mathrm{C}$ terminal domain. $\mathrm{E}$ protein is the smallest structural protein that constitutes the viral assembly, release, and pathogenesis. The $\mathrm{N}$ protein is the most abundant viral protein $(\sim 40 \mathrm{kDa})$ thus could be an ideal candidate for diagnosis ${ }^{12}$. A high immune response has been demonstrated against this protein and detected in blood and urine samples both. Despite its abundance, S proteins have also been used in COVID-19 diagnosis because of its specificity ${ }^{13}$. Studies have been reported to map the SARS-CoV-2 proteins and its antibody interaction through proteome microarray. Krishnamurthy et al have demonstrated the antibody response against four SARS-CoV-2 proteins, S1, RBD, S2, and N proteins with infected serum samples and found $98.1 \%$ sensitivity ${ }^{14}$. Wang et al. have identified specific antibodies to $\mathrm{M}, \mathrm{N}$, and $\mathrm{S}$ proteins of the virus. More than $80 \%$ of COVID-19 patients showed antibodies against four immunodominant epitopes of $\mathrm{N}, \mathrm{S}$, and Orf3a (accessory protein) residue. Interestingly, no antibodies were detected to $E$ protein ${ }^{15}$. In another proteome microarray, 29 convalescent sera of COVID-19 were used to demonstrate the $\operatorname{lgM} / \operatorname{lgG}$ response against 18 SARS-CoV-2 protein constructs. The result showed $100 \%$ antibody response mainly for $\mathrm{N}$ and $\mathrm{S} 1$ protein where $\mathrm{S} 1$ proved to be the best in differentiating COVID-19 patients from controls ${ }^{16}$.

The immunoassays which are being used prominently for recent COVID-19 diagnosis are mainly chemiluminescence immunoassay (CLIA), Enzyme-linked immunosorbent assay (ELISA) and rapid diagnostic tests (RDT) such as lateral flow immunoassay (LFIA), these detect mainly the viral structural proteins or seroconverted IgM and IgG 
antibodies in blood or serum. On $13^{\text {th }}$ March 2020 FIND had called an expression of interest for evaluation of antigen and antibody-based immunoassays from the COVID19 test manufacturers. Seven ELISA, 5 antigen detection, and 27 antibody detection RDTs have been selected for the first phase ${ }^{17}$. Immunological assays listed in the site are either comply with research use only (RUO) or in-vitro diagnostics (IVD) guidelines. IVD assays are more stringent than RUO mainly in certification and validation with real clinical samples.

\section{Antibody dynamicity through CLIA}

Since the emergence of the COVID-19 pandemic many researchers have investigated the antibody response during the disease through chemiluminescence immunoassay. A study by Jin et al. demonstrated the dynamic variance of $\lg M$ and $\lg G$ antibodies in COVID-19 patients retrospectively. Positivity of IgM antibodies increased initially then decreased over time whereas IgG positivity increased to reach $100 \%$ and every time it was higher than $\lg \mathrm{M}^{18}$. Another retrospective study done by Hu et al. observed maximum concentration of antibodies on day 19-21 whereas the highest detection rate was found to be $73.6 \%$ on day $16-18$ for $\operatorname{lgM}$ and $98.6 \%$ on day $19-21$ for $\lg$. Additionally in critical COVID-19 patients the results suggested a significantly higher concentration of $\lg G$ than mild and moderate cases ${ }^{19}$. A serological study in Italy observed $100 \%$ sensitivity for $\lg G$ than $88 \%$ for $\lg M$ at day 12 . A study from China reported $97.7 \%$ and $95.6 \%$ sensitivity and $95.2 \%$ and $96.6 \%$ specificity of $\lg M$ and $\lg G$ antibodies respectively ${ }^{21} .100 \%$ sensitivity and specificity were achieved in USA with 
commercial IgG CLIA test at day 17 from the disease onset ${ }^{22}$. In another study, seropositivity in confirmed COVID-19 patients was found within 7-12 days of disease onset and continues with disease progression. The overall specificity of $\lg M$ and $\lg G$ with non-COVID-19 suspected cases, other diseases, medical staff, and healthy controls were found to be $97 \%{ }^{8}$. Interestingly, Zeng et al. have shown comparatively higher IgG antibody in females during the early phase of SARS-CoV-2 infection and also tended to be elevated in severe cases than males ${ }^{23}$. A case-control retrospective study suggested maximum IgM level in the $4^{\text {th }}$ week of disease onset and higher in deceased patients in comparison with mild to moderate COVID-19 patients ${ }^{24}$. In a similar kind of study Xiao et al have revealed $100 \%$ positivity of $\lg M$ and $\lg G$ in the $3^{\text {rd }}$ week of disease onset. However, from the $5^{\text {th }}$ week onward IgG remained positive but $\lg M$ continued to decline ${ }^{25}$. In contrast a study using peptide derived from S protein detected IgG earlier than IgM in CLIA and as early as two days from the onset of COVID-19 symptoms. The combination of IgM and IgG showed $81.52 \%$ positivity in comparison to $57.2 \%$ and $71.4 \%$ for $\lg M$ and $\lg G$ respectively with $100 \%$ specificity to other diseases and healthy controls ${ }^{4}$. Four CLIA tests were evaluated and found to be different in performance with maximum sensitivity and specificity of $92 \%$ and $99.23 \%$ with total antibody ${ }^{26}$. In one of the studies comparing the two known antigens in CLIA suggested outperformance of RBD over $N$ protein with early responses of $\lg A$ and $\lg M$ than $\lg \mathrm{G}^{27}$. Additionally, the severity of the disease was positively correlated with the level of IgA antibody in many cases. Overall, sensitivities and specificities of $\lg A, \lg M$ and $\lg G$ tests with laboratory-confirmed patients were $98.6 \%, 96 \cdot 8 \%$, and $96 \cdot 8 \%$ and $98 \cdot 1 \%, 92.3 \%$, and $99 \cdot 8 \%$, respectively. However, after combining three antibodies the 
sensitivity and specificity reached to $99.5 \%$ and $100 \%$ respectively. A multicentric study recently reported immunoassay with COVID-19 patients of 10 hospitals in Wuhan using recombinant fusion protein constructed with fragments of $\mathrm{N}$ and $\mathrm{S}$ proteins. Virusspecific IgG showed $96.62 \%$ and $86.54 \%$ sensitivity with RT-PCR confirmed and suspected cases respectively whereas IgM showed $85.88 \%$ and $73.08 \%$. Moreover, $\lg M$ and $\lg G$ showed $97.33 \%$ and $97.43 \%$ specificity for hospitalized patients with other diseases while $99.49 \%$ and $99.15 \%$ with normal healthy individuals ${ }^{28}$. Liu et al. have demonstrated the superiority of antibody test than the nucleic acid test in moderate, severe, and critical COVID-19 cases of Wuhan retrospectively. For moderate cases positivity for $\lg M$ and $\lg G$ was $79.55 \%$ and $83.18 \%$ respectively than $65.91 \%$ for RTPCR. Severe cases showed $82.69 \%$ and $100 \%$ positive ratio for $\lg M$ and $\lg G$ respectively than $71.15 \%$ of RT-PCR whereas in critical cases ratios found to be $72.97 \%$ and $97.30 \%$ for $\operatorname{lgM}$ and $\lg$ G respectively in comparison to RT-PCR with $67.57 \%{ }^{29}$. The sensitivity and specificity obtained through CLIA are summarized in Table 1.

\section{Antibody ELISA in COVID-19 diagnosis}

Since conventional ELISA is a cumbersome and time-consuming process diagnostic companies provide precoated ELISA either with EUO or IVD labeling to detect virusspecific antibodies in human samples. However, the sensitivity and specificity of the ELISA kit largely relies on the type of viral protein used. Nevertheless, the seroconversion of antibodies in COVID-19 patients depends on the onset of symptoms, therefore, the day on which the test is being conducted should be an important 
consideration. Liu et al. have used ELISA format to detect IgM/lgG antibodies in patient's serum against SARS-CoV-2 N protein. The test showed $81.5 \%$ sensitivity with $\operatorname{lgM}$ and/or IgG at day $10^{\text {th }}$ of disease onset than $64.3 \%$ with viral RNA detection. The antibody positivity increased from $50 \%$ to $80 \%$ when tested before 5 days and after 10 days of symptom ${ }^{7}$. Zhao et al. demonstrated that within 7 days the RNA test has $66.7 \%$ sensitivity than the antibody test of only $38.3 \%$ whereas after 12 days of onset antibody detection overtook the RNA test and found to be more than $90 \%$ sensitive ${ }^{30}$. Adams et al. have shown $85 \%$ sensitivity and $100 \%$ specificity of IgM or IgG ELISA using trimeric S protein and $100 \%$ sensitivity of $\operatorname{lgG}$ after 10 or more days of disease onset ${ }^{31}$.

The dynamics of antibodies against SARS-CoV-2 showed that total antibodies can be detected first in the sample followed by IgM then IgG. Another similar kind of study revealed that antibodies increased from day 0 to day 5 and positivity rate observed from $50 \%$ to $81 \%$ for $\lg M$ and $81 \%$ to $100 \%$ for $\lg G^{5}$. Serological test with combined $\lg M$ and $\lg$ detection has increased the overall sensitivity as evident from a study where $44.4 \%$ and $82.5 \%$ sensitivities were observed for $\lg M$ and $\lg G$ independently whereas in combination sensitivity reached to $87.3 \%{ }^{32}$. Guo et al. demonstrated the sensitivities for IgM antibodies in PCR-positive confirmed and PCR-negative suspected cases which found to be $75.6 \%$ and $93.1 \%$, respectively. Moreover, a combination of IgM ELISA with PCR significantly increased the positivity to $98.6 \%$ rather than the PCR test alone $(51.9 \%)^{33}$. In contrast a cohort study in Hong Kong suggested the early seroconversion of IgG than IgM antibodies in confirmed cases. Moreover, antibodies after 14 days of disease onset showed $100 \%$ sensitivity for IgG and $94 \%$ for IgM against RBD antigen whose seropositivity was observed earlier than $\mathrm{N}$ protein ${ }^{34}$. Liu et al. confirmed that the 
S protein has high sensitivity and early antibody response than N protein in COVID-19 diagnosis. For S protein-based ELISA, the sensitivity found to be below $50 \%$ at day $0-5$ while $90.7 \%$ at day $11-15$ for IgM and/or IgG detection with $100 \%$ specificity among healthy controls ${ }^{35}$. However, a study in France compared two in-house ELISA with $\mathrm{N}$ and S SARS-CoV-2 proteins and found early antibody response against $\mathrm{N}$ protein in patients than $\mathrm{S}$ protein ${ }^{36}$. Similar study in China with $\mathrm{N}$ and $\mathrm{S}$ protein-based ELISA showed better sensitivity of $\mathrm{N}$ protein than $\mathrm{S}$ protein for $\lg \mathrm{M}$ and $\lg \mathrm{G}$ detection ${ }^{21}$. Okba et al. reported the higher specificity of $\mathrm{S} 1$ viral protein than $\mathrm{S}$ protein and showed the lower specificity of commercial serological ELISA against other coronavirus samples collected from different countries ${ }^{37}$. An ELISA in USA with S1 domain of SARS-CoV-2 showed $96.6 \%$ and $100 \%$ sensitivity for $\lg A$ and $\lg G$ detection respectively ${ }^{38}$. Lassauniere et al. recently evaluated three commercially available serological ELISA kits in Denmark and observed 65-90\% sensitivity with $93-100 \%$ specificity ${ }^{39}$. In Germany, Kohmer et al validated two commercial ELISA kits and found $58.8 \%$ and $70.6 \%$ sensitivity between day 5-9 and $93.8 \%$ and $100 \%$ between days $10-18{ }^{40}$. However, three commercial ELISAs in France demonstrated similar sensitivity of $86.7 \%$ with 80 $100 \%$ specificity ${ }^{41}$. Commercially available ELISA is cheaper than PCR diagnosis with high throughput competence and lenient sample requirement, however, unsuitable for field use is the limitation. The performance of ELISA for COVID-19 diagnosis in different countries is listed in Table 2.

\section{Rapid point of care test in SARS-CoV-2 infection}


In many infectious diseases, lateral flow immunoassay (LFIA) based immunochromatographic tests are popular for field adaptable, quick and user-friendly diagnosis. The test mainly uses colloidal gold as a tracer to detect either pathogens' antigen or its specific antibodies in the biological samples such as serum, urine, and oral fluid of patients. In the current pandemic apart from RT-PCR clinicians have searched for simple and rapid diagnosis for field settings. Therefore, many laboratories reported the LFIA based serological tests so far for COVID-19 diagnosis.

The diagnostic indexes of LFIA based IgM/lgG test were demonstrated at different time points after onset of the symptom wherein at 0-7 days, 8-15 days and 16 days or more showed $18.8 \%, 100 \%$, and $100 \%$ sensitivity and $77.8 \%, 50 \%$ and $64.3 \%$ specificity respectively ${ }^{10}$. Similar kind of study by Pan et al with RT-PCR confirmed cases showed increase in sensitivity from $11.1 \%$ to $96.8 \%$ in LFIA within first week and after two weeks of disease onset respectively. However, in RT-PCR negative suspected cases the detection capacity by LFIA was $43.6 \%{ }^{42}$. Confirmed SARS-CoV-2 infection in China suggested $23 \%$ and $63.8 \%$ detectability of IgM and IgG LFIA test respectively in an early phase of illness which were poor than $92.3 \%$ with RNA test from sputum. Between 8-14 days the sensitivity of $\lg M$ and $\lg G$ increased to $50 \%$ and $87.5 \%$ respectively. However, at 15 days or more the sensitivity rose to $52.2 \%$ and $91.3 \%$ for $\lg M$ and $\lg G$ respectively than $60.8 \%$ for molecular test ${ }^{6}$. Study in Germany with IgM/IgG LFIA showed $93.8 \%$ sensitivity from $10-18$ days of PCR test than $62.5 \%$ from days $5-940$. Another LFIA in Brazil showed $77.1 \%$ sensitivity and $98 \%$ specificity after at least 10 days when tested positive for RT-PCR ${ }^{43}$. A case report from Taiwan investigated IgG response against SARS-CoV-2 in LFIA and observed its appearance after 18-21 days 
of exposure or the $11^{\text {th }}$ day of illness ${ }^{44}$. A study from Spain suggested the use of antibody tests after at least 14 days of disease onset as they found $73.9 \%$ sensitivity at this time point as compared to $12.5 \%$ and $33.3 \%$ at $0-7$ days and $7-13$ days respectively 45.

Li et al. developed and evaluated IgM and IgG based lateral flow tests using the recombinant RBD domain of S protein. Results interpreted with both IgM and IgG bands showed $88.66 \%$ sensitivity and $90.63 \%$ specificity which were better than single $\lg M$ and IgG tests ${ }^{46}$. One similar study showed $82.4 \%$ sensitivity including both serum IgM and $\lg G$ as compared to $57.1 \%$ and $81.3 \%$ for $\lg M$ and $\lg G$ alone with $100 \%$ specificity in each case ${ }^{32}$. Similar study in the USA with defined cases estimated $91.8 \%$ sensitivity and $99.5 \%$ specificity ${ }^{32}$. Moreover, Hu et al. have detected $63.4 \%$ of $\operatorname{lgM} / \lg$ G positives in the blood of clinically suspected cases through LFIA than $46.3 \%$ from nasal or pharyngeal swab specimens through RT-PCR ${ }^{47}$.

Study by the National COVID Testing Scientific Advisory Panel, UK evaluated nine commercially available different LFIA tests for COVID-19 detection. The overall sensitivities of LFIA tests after 10 days of disease onset ranged from $55-70 \%$ as compared to RT-PCR with $95-100 \%$ specificities. Therefore, the report suggested inadequacy of the LFIA test to diagnose COVID-19 with the current performance ${ }^{31}$. Low sensitivity of LFIA test was also observed in two separated studies in Iran and Germany with $47.9 \%$ and $36.4 \%$ sensitivities respectively ${ }^{48,49}$. Another study in Denmark validated four commercially available lateral flow tests with a similar number of confirmed COVID-19 cases and found sensitivities ranged from $83-93 \%$ with $100 \%$ specificity for all LFIA ${ }^{39}$. Ten LFIA tests were validated in USA with RT-PCR positive 
samples and found $81.8-100 \%$ sensitivity and $84.3-100 \%$ specificity after 20 days of disease onset ${ }^{50}$. Rashid et al have reported a review on nine commercial rapid LFIA tests and observed $72.7-100 \%$ sensitivity and $98.7-100 \%$ specificity of antibody tests ${ }^{51}$. A study in France with six POCs showed sensitivity ranges between $76.9 \%$ and $93.3 \%$ and specificity between $65 \%$ and $100 \%{ }^{41}$. The performance of a commercial $\operatorname{lgM} / \operatorname{lgG}$ LFIA test was also reported with hospitalized and emergency department COVID-19 patients in Italy. At a median of 7 days only $63.3 \%$ of patients showed positivity with LFIA. Patients from the emergency department showed only $18.45 \%$ and $8.3 \%$ positivity with RT-PCR positive and negative cases respectively thus not recommended the use of LFIA for suspected COVID-19 cases ${ }^{52}$. Study in Japan with a commercial one step test did not recommend the antibody test alone for initial diagnosis ${ }^{53}$. Research conducted throughout the world so far has mix response for utility of LFIA test in COVID-19 diagnosis. The overall percentage of sensitivity and specificity of LFIA in different countries is compiled in Table 3 . Figure 1 depicts the diagnostic performance of immune assays throughout the countries.

\section{A hunt for asymptomatic cases}

The world has faced bigger pandemics in the past. The virus has infected humans before in the form of SARS and MERS. Then why the scare and why call the pandemic unprecedented? The severity of a disease depends on its transmission rate and death rate. Unlike SARS $\left(R_{0=}\right)$, the transmission rate of COVID-19 is suspected to be very high especially through asymptomatic cases, with an average $R_{0}$ value of around $3.28{ }^{54}$. Thereby increasing the chances of spread due to these undetected asymptomatic cases 
through leaps and bounds through contacts or expelling air droplets ${ }^{3}$. Li et al. demonstrated human to human SARS-CoV-2 transmission from asymptomatic when studied in two family clusters in China ${ }^{55}$. A case report by Zhu et al. also highlighted a SARS-CoV-2 infection from asymptomatic contact ${ }^{56}$. A study in Germany also suggested the transmissions of COVID-19 from asymptomatic during his incubation period ${ }^{57}$. Since the inception of the COVID-19 infection, most of the studies are limited to the symptomatic cases thus not many details have been reported to access the asymptomatic cases. According to a report from the National Health Commission in China, $78 \%$ of the total identified SARS-CoV-2 cases within 24 hours on $1^{\text {st }}$ April 2020 were asymptomatic ${ }^{58}$. Moreover, a case study from the Diamond Princess Cruise ship estimated around $17.9 \%$ of asymptomatic cases occurred with this infection ${ }^{59}$. Therefore, it is suspected that the undetected asymptomatic cases are underestimated and may result in an increase in the total number of reported COVID-19 infections ${ }^{60}$. A community-based study in the USA County through rapid antibody test recognized population prevalence of $2.49 \%-4.16 \%$ for COVID-19. Thus an estimated 50 to 80 times higher number of cases than confirmed cases ${ }^{61}$. Another study in USA with 4856 individuals in population detected 87 (1.79\%) SARS-CoV-2 positives with lgG test ${ }^{22}$. Similar kind of study in Iran found 22\% prevalence of COVID-19 and estimated higher number of confirmed cases than expected ${ }^{62}$. A population-based survey in Brazil with 4188 subjects showed increase in positivity from $0.04 \%$ to $0.133 \%$ within two weeks of mid April ${ }^{63}$. Recently a systemic review published with preliminary data of 83 asymptomatic cases in nine articles observed significant contribution of asymptomatic and pre-symptomatic patients in the spread of SARS-CoV-2 infection ${ }^{64}$. Samples 
collected from the oral swab, BAL fluid, and stool in one of the studies reported higher viral load in nasopharyngeal samples. However, this variation in viral load is negligible in symptomatic and asymptomatic cases. Confirmed tests were reported through RTPCR in some individuals without having any COVID-19 symptoms ${ }^{65}$. Interestingly, an asymptomatic case report from China showed positive nucleic acid test with urine samples before throat swab suggested the need for other means of diagnosis too for asymptomatic cases ${ }^{66}$.

Since health care workers are the front runners in this pandemic many studies have focused on their screening for asymptomatic infection. Study with health care workers having mild respiratory symptoms from nine hospitals in Netherland identified $4.1 \%$ SARS-CoV-2 positive cases ${ }^{67}$. Another test with residents of health care providers in Washington reported a $30.3 \%$ prevalence of infection in the facility ${ }^{68}$. Seroprevalence of SARS-CoV-2 infection in healthcare workers from two community clinics in Japan observed $9.1 \%$ positivity rate in comparison to the overall rate of $5.9 \%{ }^{69}$. Samples collected randomly from health professionals in Spain depicted $11.2 \%$ of cumulative prevalence in antibody quantification ${ }^{70}$. Study reported from Italy showed $5.25 \%$ seropositivity within the asymptomatic healthcare providers ${ }^{71}$. In contrast, another study from Italy screened health workers and observed discordant results between two immunological assays in reporting sensitivity ${ }^{72}$. It is evident from the knowledge gathered from the initial studies so far that asymptomatic cases have a significant role in COVID-19 spread. More studies are needed to understand the immune response and spread pattern in asymptomatic infection. To deal with the extra challenge of asymptomatic carriers a widespread testing is needed within the hotspot community 
more systematically. The test should be ideally for onsite detection and rapid in which antigen or antibody-based immunoassays could be a critical success factor for mass level testing of COVID-19.

\section{Conclusion}

Like any previous pandemic, the answer to curing the disease will be an appropriate vaccine strategy. However, the solution to managing COVID-19 till then cannot be limited to any one thing, it has to be a holistic approach, like the WHO Director-General Tedros Adhanom mentioned, "Not testing alone. Not contact tracing alone. Not quarantine alone. Not social distancing alone. Do it all."

The world cannot be kept in standstill and lockdown for an indefinite period. We may have to withdraw the lockdowns gradually expose our populations little by little to the virus so that a natural immunity is developed in our populations without causing a massacre. Until then, the most appropriate solution to combat this death-knell will be extensive diagnosis, identification of the asymptomatic carriers and symptomatic patients, marking and isolating them. While RT-PCRs are good options for detecting the virus, their cumbersome protocols, time and expense, does not make them suitable candidates for mass testing, urging for alternative tests. Rapid tests are quintessential for detecting a mass population because of its ease of use, less time consumption, and low cost, and thus may be used complementary to RT- PCRs. However, rapid tests too have their limitations of performance, and sensitivity. Since most of the serological tests have been reported at different time points it is difficult to access the correct time line for seroconversion against SARS-CoV-2 infection. The seropositivity of the antibody test 
within the first week of disease onset is not satisfactory in many cases. However, sensitivity escalates to $80-100 \%$ in the second week combining both $\operatorname{lgM}$ and $\lg G$ in the interpretation. Nevertheless, serological tests can complement the nucleic acid tests largely for the false negative case detection. Additionally, serological tests mainly in the point-of-care format can be used for surveillance strategy within the community. However, un-regulation or misuse of these rapid tests can create an extra panic in society.

The current phase can very well be called the testing times, where various diagnostic tests, vaccines, drugs are in trails and tremendous effort is being put by many across the globe to put an end to this pandemic. The human race has faced various virus attacks, and has forever fought to strive through the battle. The fight too will be a long one, and the key to success will be continuous efforts. Herein our review aims to enumerate all the important diagnostic findings together to help strategize ways to deal with this global pandemic.

\section{Acknowledgments}

The authors want to thank CSIR-Indian Institute of Chemical Biology, Kolkata.

\section{Disclosure statement}

The authors declare that they have no competing interests.

\section{Funding}


This work has, in part, received funding from UK Research and Innovation via the Global Challenges Research Fund under grant agreement 'A Global Network for Neglected Tropical Diseases' grant number MR/P027989/1, Sir J. C. Bose Fellowship, India, Fellowships from Council of Scientific and Industrial Research and Indian Council of Medical Research, India.

\section{References}

$1 \quad$ Lv H, Wu NC, Tsang OT-Y, Yuan M, Perera RAPM, Leung WS et al. Crossreactive antibody response between SARS-CoV-2 and SARS-CoV infections. bioRxiv 2020; : 2020.03.15.993097.

2 Coronavirus Update (Live): 4,084,372 Cases and 279,467 Deaths from COVID-19 Virus Pandemic - Worldometer. https://www.worldometers.info/coronavirus/\#countries (accessed 10 May2020).

3 Udugama B, Kadhiresan P, Kozlowski HN, Malekjahani A, Osborne M, Li VYC et al. Diagnosing COVID-19: The Disease and Tools for Detection. ACS Nano 2020; 14. doi:10.1021/acsnano.0c02624.

4 Cai X-f, Chen J, Hu J-i, Long Q-x, Deng H-j, Fan K et al. Peptide-based Magnetic Chemiluminescence Enzyme Immunoassay for Serological Diagnosis of Coronavirus Disease 2019 (COVID-19) | The Journal of Infectious Diseases | Oxford Academic. https://academic.oup.com/jid/advancearticle/doi/10.1093/infdis/jiaa243/5831993 (accessed 10 May2020).

5 Zhang W, Du RH, Li B, Zheng XS, Yang X Lou, Hu B et al. Molecular and serological investigation of 2019-nCoV infected patients: implication of multiple shedding routes. Emerg Microbes Infect 2020; 9: 386-389.

6 Yong G, Yi Y, Tuantuan L, Xiaowu W, Xiuyong L, Ang L et al. Evaluation of the 
auxiliary diagnostic value of antibody assays for the detection of novel coronavirus (SARS-CoV-2). J Med Virol 2020. doi:10.1002/jmv.25919.

7 Liu L, Liu W, Wang S, Zheng S. A preliminary study on serological assay for severe acute respiratory syndrome coronavirus 2 (SARS-CoV-2) in 238 admitted hospital patients. medRxiv 2020; : 2020.03.06.20031856.

8 Zhang J, Liu J, Li N, Liu Y, Ye R, Qin X et al. Serological detection of 2019-nCoV respond to the epidemic: A useful complement to nucleic acid testing. medRxiv 2020; : 2020.03.04.20030916.

9 SARS-CoV-2 molecular assay evaluation: results - FIND. https://www.finddx.org/covid-19/sarscov2-eval-molecular/molecular-eval-results/ (accessed 10 May2020).

10 Liu Y, Liu Y, Diao B, Ren F, Wang Y, Ding J et al. Diagnostic Indexes of a Rapid IgG/lgM Combined Antibody Test for SARS-CoV-2. medRxiv 2020; : 2020.03.26.20044883.

11 Jiang S, Hillyer C, Du L. Neutralizing Antibodies against SARS-CoV-2 and Other Human Coronaviruses. Trends Immunol. 2020; 41: 355-359.

12 Kumar S, Maurya VK, Prasad AK, Bhatt MLB, Saxena SK. Structural, glycosylation and antigenic variation between 2019 novel coronavirus (2019$\mathrm{nCoV}$ ) and SARS coronavirus (SARS-CoV). VirusDisease 2020; 31: 13-21.

13 Vashist SK. In vitro diagnostic assays for COVID-19: Recent advances and emerging trends. Diagnostics. 2020; 10. doi:10.3390/diagnostics10040202.

14 Krishnamurthy HK, Jayaraman V, Krishna K, Rajasekaran KE, Wang T, Bei K et al. Antibody Profiling and Prevalence in the US population during the SARS-CoV2 Pandemic. medRxiv 2020; : 2020.04.29.20085068.

15 Wang H, Hou X, Wu X, Liang T, Zhang X, Wang D et al. SARS-CoV-2 proteome microarray for mapping COVID-19 antibody interactions at amino acid resolution. bioRxiv 2020; : 2020.03.26.994756. 
16 Jiang $\mathrm{H}$, Li Y, Zhang H, Wang W, Men D, Yang $X$ et al. Global profiling of SARSCoV-2 specific lgG/ IgM responses of convalescents using a proteome microarray. medRxiv 2020; : 2020.03.20.20039495.

17 FIND evaluation update: SARS-CoV-2 immunoassays - FIND. https://www.finddx.org/covid-19/sarscov2-eval-immuno/ (accessed 10 May2020).

18 Jin Y, Wang M, Zuo Z, Fan C, Ye F, Cai Z et al. Diagnostic value and dynamic variance of serum antibody in coronavirus disease 2019. Int $J$ Infect Dis 2020; 94: 49-52.

19 Hu Q, Cui X, Liu X, Peng B, Jiang J, Wang X et al. The production of antibodies for SARS-CoV-2 and its clinical implication. medRxiv 2020; : 2020.04.20.20065953.

20 Padoan A, Cosma C, Sciacovelli L, Faggian D, Plebani M. Analytical performances of a chemiluminescence immunoassay for SARS-CoV-2 $\operatorname{lgM} / \mathrm{lgG}$ and antibody kinetics. Clin Chem Lab Med 2020. doi:10.1515/cclm-2020-0443.

21 Zhong L, Chuan J, Gong B, Shuai P, Zhou Y, Zhang Y et al. Detection of serum IgM and IgG for COVID-19 diagnosis. Sci. China Life Sci. 2020; 63: 777-780.

22 Bryan A, Pepper G, Wener MH, Fink SL, Morishima C, Chaudhary A et al. Performance Characteristics of the Abbott Architect SARS-CoV-2 IgG Assay and Seroprevalence in Boise, Idaho. J Clin Microbiol 2020. doi:10.1128/JCM.0094120.

23 Zeng F, Dai C, Cai P, Wang J, Xu L, Li J et al. A comparison study of SARS-CoV-2 IgG antibody between male and female COVID-19 patients: a possible reason underlying different outcome between sex. J Med Virol 2020; : jmv.25989.

24 Wang Z, Li H, Li J, Yang C, Guo X, Hu Z et al. Elevated serum IgM levels indicate poor outcome in patients with coronavirus disease 2019 pneumonia: $A$ retrospective case-control study. medRxiv 2020; : 2020.03.22.20041285. 
25 Xiao AT, Gao C, Zhang S. Profile of specific antibodies to SARS-CoV-2: The first report. J. Infect. 2020. doi:10.1016/j.jinf.2020.03.012.

26 Wan Y, Li Z, Wang K, Li T, Liao P. Performance verification of detecting COVID19 specific antibody by using four chemiluminescence immunoassay systems. medRxiv 2020; : 2020.04.27.20074849.

27 Ma H, Zeng W, He H, Zhao D, Yang Y, Jiang D et al. COVID-19 diagnosis and study of serum SARS-CoV-2 specific $\lg A$, $\lg M$ and $\lg G$ by a quantitative and sensitive immunoassay. medRxiv 2020; : 2020.04.17.20064907.

28 Qian C, Zhou M, Cheng F, Lin X, Gong Y, Xie X et al. Development and Multicenter Performance Evaluation of The First Fully Automated SARS-CoV-2 IgM and IgG Immunoassays. medRxiv 2020; : 2020.04.16.20067231.

29 Liu R, Liu X, Han H, Shereen MA, Niu Z, Li D et al. The comparative superiority of $\lg M-\lg G$ antibody test to real-time reverse transcriptase PCR detection for SARSCoV-2 infection diagnosis. medRxiv 2020; : 2020.03.28.20045765.

30 Zhao J, Yuan Q, Wang H, Liu W, Liao X, Su, Y et al. Antibody Responses to SARS-CoV-2 in Patients of Novel Coronavirus Disease 2019 - PubMed. https://pubmed.ncbi.nlm.nih.gov/32221519/ (accessed 10 May2020).

31 Adams ER, Anand R, Andersson MI, Auckland K, Baillie JK, Barnes E et al. Evaluation of antibody testing for SARS-Cov-2 using ELISA and lateral flow immunoassays. medRxiv 2020; : 2020.04.15.20066407.

32 Xiang J, Yan M, Li H, Liu T, Lin C, Huang S et al. Evaluation of Enzyme-Linked Immunoassay and Colloidal Gold- Immunochromatographic Assay Kit for Detection of Novel Coronavirus (SARS-Cov-2) Causing an Outbreak of Pneumonia (COVID-19). medRxiv 2020; : 2020.02.27.20028787.

33 Guo L, Ren L, Yang S, Xiao M, Chang D, Yang F et al. Profiling Early Humoral Response to Diagnose Novel Coronavirus Disease (COVID-19) | Clinical Infectious Diseases | Oxford Academic. https://academic.oup.com/cid/advance- 
article/doi/10.1093/cid/ciaa310/5810754 (accessed 10 May2020).

34 To KKW, Tsang OTY, Leung WS, Tam AR, Wu TC, Lung DC et al. Temporal profiles of viral load in posterior oropharyngeal saliva samples and serum antibody responses during infection by SARS-CoV-2: an observational cohort study. Lancet Infect Dis 2020; 20: 565-574.

35 Liu W, Liu L, Kou G, Zheng Y, Ding Y, Ni W et al. Evaluation of Nucleocapsid and Spike Protein-based ELISAs for detecting antibodies against SARS-CoV-2. J Clin Microbiol 2020. doi:10.1128/JCM.00461-20.

36 Grzelak L, Temmam S, Planchais C, Demeret C, Huon C, Guivel F et al. SARSCoV-2 serological analysis of COVID-19 hospitalized patients, pauci-symptomatic individuals and blood donors. medRxiv 2020; : 2020.04.21.20068858.

37 Okba NMA, Muller MA, Li W, Wang C, GeurtsvanKessel CH, Corman VM et al. SARS-CoV-2 specific antibody responses in COVID-19 patients. medRxiv 2020; : 2020.03.18.20038059.

38 Matushek SM, Beavis KG, Abeleda A, Bethel C, Hunt C, Gillen S et al. Evaluation of the EUROIMMUN Anti-SARS-CoV-2 ELISA Assay for detection of IgA and IgG antibodies. bioRxiv 2020; : 2020.05.11.089862.

39 Lassaunière R, Frische A, Harboe ZB, Nielsen AC, Fomsgaard A, Krogfelt KA et al. Evaluation of nine commercial SARS-CoV-2 immunoassays. medRxiv 2020; : 2020.04.09.20056325.

40 Kohmer N, Westhaus S, Rühl C, Ciesek S, Rabenau HF. Clinical performance of SARS-CoV-2 IgG antibody tests and potential protective immunity. bioRxiv 2020; : 2020.05.08.085506.

41 TUAILLON E. Detection of SARS-CoV-2 antibodies using commercial assays and seroconversion patterns in hospitalized patients. medRxiv 2020; : 2020.05.04.20090027.

42 Pan Y, Li X, Yang G, Fan J, Tang Y, Zhao J et al. Serological 
immunochromatographic approach in diagnosis with SARS-CoV-2 infected COVID-19 patients. J Infect 2020. doi:10.1016/j.jinf.2020.03.051.

43 Pellanda LC, Wendland EM, McBride AJ, Tovo-Rodrigues L, Ferreira MR, Dellagostin OA et al. Sensitivity and specificity of a rapid test for assessment of exposure to SARS-CoV-2 in a community-based setting in Brazil. medRxiv 2020; : 2020.05.06.20093476.

44 Lee NY, Li CW, Tsai HP, Chen PL, Syue LS, Li MC et al. A case of COVID-19 and pneumonia returning from Macau in Taiwan: Clinical course and anti-SARSCoV-2 IgG dynamic. J Microbiol Immunol Infect 2020. doi:10.1016/j.jmii.2020.03.003.

45 Garcia FP, Tanoira RP, Cabrera JPR, Serrano TA, Herruz PG, Gonzalez JC. Rapid diagnosis of SARS-CoV-2 infection by detecting IgG and IgM antibodies with an immunochromatographic device: a prospective single-center study. medRxiv 2020; : 2020.04.11.20062158.

46 Li Z, Yi Y, Luo X, Xiong N, Liu Y, Li S et al. Development and clinical application of a rapid IgM-IgG combined antibody test for SARS-CoV-2 infection diagnosis. $J$ Med Virol 2020. doi:10.1002/jmv.25727.

47 Hu X, Deng H, Shang Y, Fan M, Yue F. Simple Strategy for Rapid and Sensitive Detection of 2019 novel coronavirus Based on Antibody. 2020. doi:10.21203/RS.3.RS-16761/V1.

48 Shamsollahi HR, Amini M, Alizadeh S, Nedjat S, Akbari-Sari A, Rezaei M et al. Assessment of a serological diagnostic kit of sars-cov-2 availble in Iran. medRxiv 2020; : 2020.05.04.20090209.

49 Döhla M, Boesecke C, Schulte B, Diegmann C, Sib E, Richter E et al. Rapid point-of-care testing for SARS-CoV-2 in a community screening setting shows low sensitivity. Public Health 2020; 182: 170-172.

50 Whitman JD, Hiatt J, Mowery CT, Shy BR, Yu R, Yamamoto TN et al. Test 
performance evaluation of SARS-CoV-2 serological assays. medRxiv 2020; : 2020.04.25.20074856.

51 Zainol Rashid Z, Othman SN, Abdul Samat MN, Ali UK, Wong KK. Diagnostic performance of COVID-19 serology assays. Malays J Pathol 2020; 42: 13-21.

52 Cassaniti I, Novazzi F, Giardina F, Salinaro F, Sachs M, Perlini S et al. Performance of VivaDiag COVID-19 IgM/lgG Rapid Test is inadequate for diagnosis of COVID-19 in acute patients referring to emergency room department. J. Med. Virol. 2020. doi:10.1002/jmv.25800.

53 Imai K, Tabata S, Ikeda M, Noguchi S, Kitagawa Y, Matuoka M et al. Clinical evaluation of an immunochromatographic $\operatorname{lgM} / \lg G$ antibody assay and chest computed tomography for the diagnosis of COVID-19. J Clin Virol 2020; 128: 104393.

54 Liu Y, Gayle AA, Wilder-Smith A, Rocklöv J. The reproductive number of COVID19 is higher compared to SARS coronavirus. J Travel Med 2020; 27. doi:10.1093/jtm/taaa021.

55 Li C, Ji F, Wang L, Wang L, Hao J, Dai M et al. Asymptomatic and Human-toHuman Transmission of SARS-CoV-2 in a 2-Family Cluster, Xuzhou, China. Emerg Infect Dis 2020; 26. doi:10.3201/eid2607.200718.

56 Zhu C-Q, Gao S-D, Yang X-H, Ye F-Q, Ai L-L, Lv R-C et al. A COVID-19 Case Report from Asymptomatic Contact: Implication for Contact Isolation and Incubation Management. Preprints, 2020www.preprints.org (accessed 10 May2020).

57 Rothe C, Schunk M, Sothmann P, Bretzel G, Froeschl G, Wallrauch C et al. Transmission of 2019-NCOV infection from an asymptomatic contact in Germany. N. Engl. J. Med. 2020; 382: 970-971.

58 Day M. Covid-19: four fifths of cases are asymptomatic, China figures indicate. BMJ 2020; 369: m1375. 
59 Mizumoto K, Kagaya K, Zarebski A, Chowell G. Estimating the asymptomatic proportion of coronavirus disease 2019 (COVID-19) cases on board the Diamond Princess cruise ship, Yokohama, Japan, 2020. Eurosurveillance. 2020; 25. doi:10.2807/1560-7917.ES.2020.25.10.2000180.

60 Wang D, Hu B, Hu C, Zhu F, Liu X, Zhang J et al. Clinical Characteristics of 138 Hospitalized Patients with 2019 Novel Coronavirus-Infected Pneumonia in Wuhan, China. JAMA - J Am Med Assoc Wang D, Hu B, Hu C al Clin Charact 138 Hosp Patients with 2019 Nov Coronavirus-Infected Pneumonia Wuhan, China JAMA - J Am Med Assoc 2020; 323 1061-1069 2020; 323: 1061-1069.

61 Bendavid E, Mulaney B, Sood N, Shah S, Ling E, Bromley-Dulfano R et al. COVID-19 Antibody Seroprevalence in Santa Clara County, California. medRxiv 2020; : 2020.04.14.20062463.

62 Shakiba M, Nazari SSH, Mehrabian F, Rezvani SM, Ghasempour Z, Heidarzadeh A. Seroprevalence of COVID-19 virus infection in Guilan province, Iran. medRxiv 2020; : 2020.04.26.20079244.

63 Silveira M, Barros A, Horta B, Pellanda L, Victora G, Dellagostin O et al. Repeated population-based surveys of antibodies against SARS-CoV-2 in Southern Brazil. medRxiv 2020; : 2020.05.01.20087205.

64 Aguirre-Duarte N. Can people with asymptomatic or pre-symptomatic COVID-19 infect others: a systematic review of primary data. medRxiv 2020; : 2020.04.08.20054023.

65 Dong X, Cao Y yuan, Lu X xia, Zhang J jin, Du H, Yan Y qin et al. Eleven faces of coronavirus disease 2019. Allergy Eur J Allergy Clin Immunol 2020. doi:10.1111/all.14289.

66 Ren J, Li D, Wang C, Zhang X, Wu J, Wang Y et al. Urine nucleic acid test positive in an asymptomatic patient with novel coronavirus 2019 infection: a\&nbsp;case report. 2020. doi:10.21203/RS.3.RS-22292/V1. 
67 Reusken CB, Buiting A, Bleeker-Rovers C, Diederen B, Hooiveld M, Friesema I et al. Rapid assessment of regional SARS-CoV-2 community transmission through a convenience sample of healthcare workers, the Netherlands, March 2020. Eurosurveillance. 2020; 25. doi:10.2807/1560-7917.ES.2020.25.12.2000334.

68 Kimball A, Hatfield KM, Arons M, James A, Taylor J, Spicer K et al. Asymptomatic and presymptomatic SARS-COV-2 infections in residents of a long-term care skilled nursing facility - King County, Washington, March 2020. Morb. Mortal. Wkly. Rep. 2020; 69: 377-381.

69 Takita M, Matsumura T, Yamamoto K, Yamashita E, Hosoda K, Hamaki T et al. Preliminary Results of Seroprevalence of SARS-CoV-2 at Community Clinics in Tokyo. medRxiv 2020; : 2020.04.29.20085449.

70 Garcia-Basteiro AL, Moncunill G, Tortajada M, Vidal M, Guinovart C, Jimenez A et al. Seroprevalence of antibodies against SARS-CoV-2 among health care workers in a large Spanish reference hospital. medRxiv 2020; : 2020.04.27.20082289.

71 Tosato F, Pelloso M, Gallo N, Giraudo C, Llanaj G, Cosma C et al. Severe Acute Respiratory Syndrome Coronavirus 2 Serology in Asymptomatic Healthcare Professionals: Preliminary Experience of a Tertiary Italian Academic Center. medRxiv 2020; : 2020.04.27.20073858.

72 Paradiso AV, Summa simona De, Silvestris N, Tommasi S, Tufaro A, Palma G De et al. RAPID SEROLOGICAL TESTS HAVE A ROLE IN ASYMPTOMATIC HEALTH WORKERS COVID-19 SCREENING. medRxiv 2020; : 2020.04.15.20057786. 


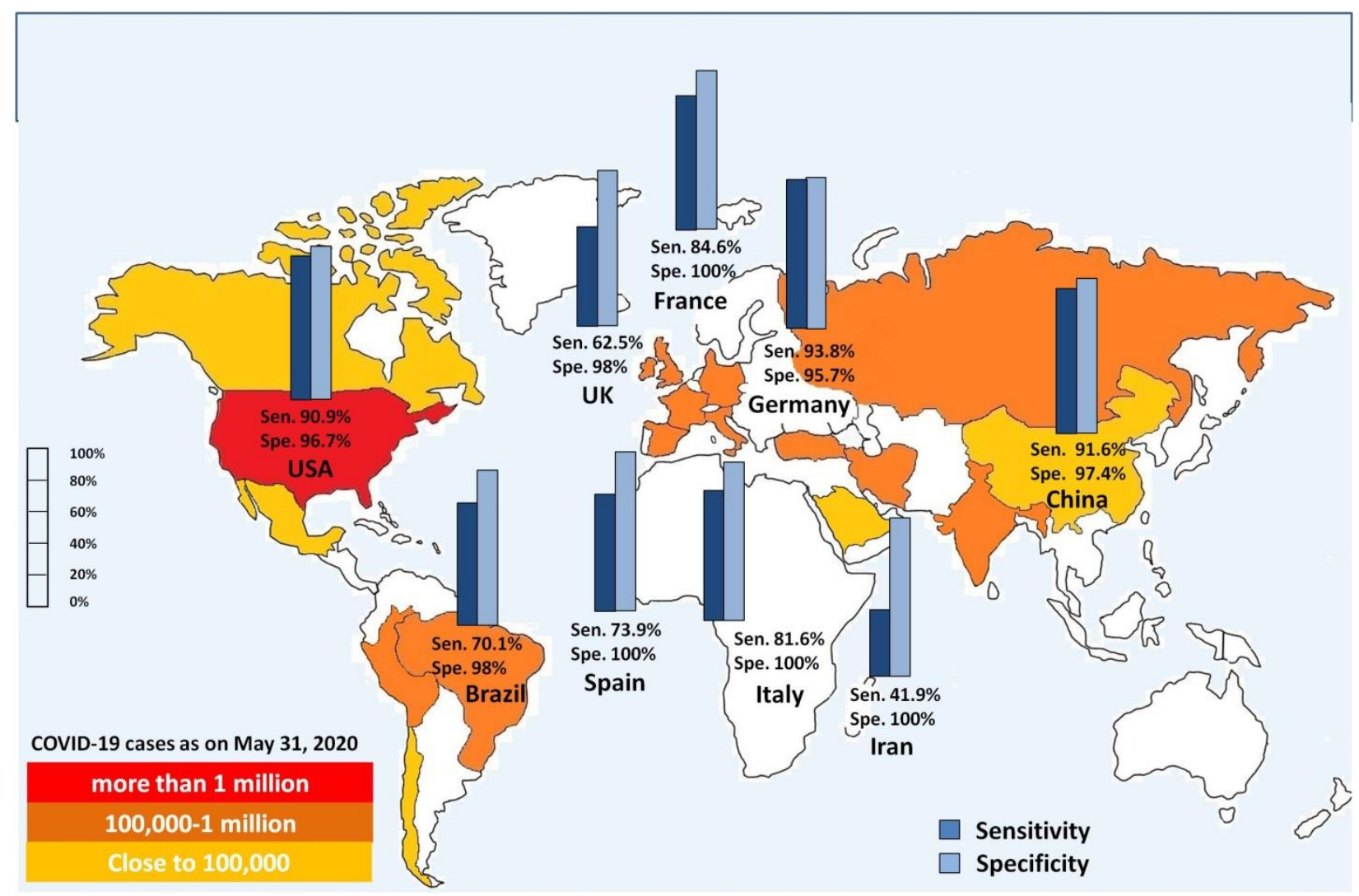

Figure 1: The figure represents the combined sensitivity and specificity of immuno assays including chemiluminescence (CLIA), enzyme-linked (ELISA) and lateral flow tests (LFIA) reported across the countries. The sensitivity and specificity were aggregated from 19 studies in China, 4 studies from USA, 2 studies each from Italy, Germany, and France, and single study each from UK, Spain, Iran and Brazil. 
Table 1: Performance of CLIA serological test in different countries.

\begin{tabular}{|c|c|c|c|c|c|c|}
\hline Country & $\begin{array}{l}\text { COVID-19 } \\
\text { cases/ } \\
\text { nonCOVID-19 } \\
\text { cases }\end{array}$ & Antibodies & $\begin{array}{l}\text { Days from } \\
\text { disease } \\
\text { onset }\end{array}$ & Sensitivity \% & Specificity \% & Reference \\
\hline China & $43 / 33$ & $\operatorname{lgM} / \operatorname{lgG}$ & $\begin{array}{l}\text { Median } \\
16 d\end{array}$ & $48.1 / 88.9$ & $100 / 90.9$ & [18] \\
\hline China & $276 / 367$ & $\begin{array}{l}\lg M / \lg G \\
\lg M+\lg G\end{array}$ & -- & $\begin{array}{l}57.2 / 71.4 \\
81.52\end{array}$ & 100 & [4] \\
\hline China & 34 & $\lg M / \lg G$ & $\begin{array}{l}3^{\text {rd }} \text { week } \\
5^{\text {th }} \text { week }\end{array}$ & $\begin{array}{l}100 / 100 \\
94.1 / 100\end{array}$ & -- & [25] \\
\hline China & $3 / 736$ & $\lg M / \lg G$ & 7-12d, & 100 & $97.3-100$ & [8] \\
\hline China & 133 & $\lg M / \lg G$ & -- & $\begin{array}{l}72.9-82.6 / \\
93.1-100\end{array}$ & 65.9-71.1 & [29] \\
\hline China & $87 / 483$ & $\lg A / \operatorname{lgM} / \lg G$ & -- & 98.6/96.8/96.8 & 98.1/92.3/99.8 & [27] \\
\hline China & $555 / 1558$ & $\lg M / \lg G$ & $3-35 d$ & $\begin{array}{l}73.0-85.8 / \\
86.5-96.6\end{array}$ & $\begin{array}{l}97.3-99.4 / \\
97.4-99.1\end{array}$ & [28] \\
\hline China & 221 & $\lg M / \lg G$ & $16-21 d$ & 73.6/98.6 & -- & [19] \\
\hline US & $125 / 1020$ & $\lg G$ & $17 d$ & 100 & 99.9 & [22] \\
\hline China & $50 / 130$ & $\begin{array}{l}\lg M / \operatorname{lgG} \\
4 \mathrm{CLIA}\end{array}$ & $13 d$ & 92 & 99.23 & [26] \\
\hline Italy & 87 & $\lg M / \lg G$ & $12 d$ & $88 / 100$ & -- & [20] \\
\hline China & $47 / 300$ & $\lg M / \lg G$ & -- & $97.7 / 95.6$ & $95.2 / 96.6$ & [21] \\
\hline
\end{tabular}


Table 2: Performance of antibody ELISA test in different countries.

\begin{tabular}{|c|c|c|c|c|c|c|}
\hline Country & $\begin{array}{l}\text { COVID-19 } \\
\text { cases/ } \\
\text { nonCOVID-19 } \\
\text { cases }\end{array}$ & Antibodies & $\begin{array}{l}\text { Days from } \\
\text { disease } \\
\text { onset }\end{array}$ & Sensitivity \% & Specificity \% & Reference \\
\hline China & $238 / 120$ & $\mathrm{Ab} / \operatorname{lgM} / \lg G$ & $5 d$ & 81.5 & $94.2-100$ & [7] \\
\hline China & 173 & $\mathrm{Ab} / \lg \mathrm{g} / \lg M$ & $<15 d$ & $\begin{array}{l}100,94.3 \\
79.8\end{array}$ & -- & [30] \\
\hline China & 178 & $\lg M / \lg G$ & $\begin{array}{l}0 d \\
5 d\end{array}$ & $\begin{array}{l}50 / 81 \\
81 / 100\end{array}$ & -- & [5] \\
\hline China & $63 / 35$ & $\lg M / \lg G$ & $1-28 d$ & 87.3 & 100 & [32] \\
\hline China & $214 / 100$ & $\lg M / \lg G$ & $\begin{array}{l}0-5 d \\
11-15 d\end{array}$ & $\begin{array}{l}45.5 \\
90.7\end{array}$ & 100 & [35] \\
\hline China & 208/285 & $\lg A / \lg M / \lg G$ & $\begin{array}{l}5-14 d \\
\text { median }\end{array}$ & $92.7 / 85.4 / 77.9$ & 100 & [33] \\
\hline China & 23 & $\lg M / \lg G$ & $14 d<$ & $88-94 / 94-100$ & -- & [34] \\
\hline Denmark & $30 / 82$ & $\begin{array}{l}\lg \mathrm{G} / \lg \mathrm{M}, \\
\lg \mathrm{A} \\
3 \mathrm{ELISA}\end{array}$ & -- & $65-90$ & $93-100$ & [39] \\
\hline UK & $40 / 142$ & $\lg M / \lg G$ & $<28 d$ & 85 & 100 & [31] \\
\hline France & $51 / 200$ & $\lg M / \lg G$ & $5-14 d$ & $65-69$ & 100 & [36] \\
\hline Germany & 17/13-26 & $\lg A, \lg G$ & $5-9 d$ & $58.8-70.6$ & $95.2-95.7$ & [40] \\
\hline
\end{tabular}




\begin{tabular}{|c|c|c|c|c|c|c|}
\hline & & 2 ELISA & $10-18 d$ & $93.8-100$ & & \\
\hline \multirow[t]{2}{*}{ France } & $15 / 20$ & $\lg A, \lg G$ & $15 d<$ & 86.7 & $80-100$ & [41] \\
\hline & & 3 ELISA & & & & \\
\hline \multirow[t]{2}{*}{ China } & $47 / 300$ & $\operatorname{lgM} / \lg G$ & -- & 89.1-7.9/ & 97-99.7/ & [21] \\
\hline & & & & $95.7-97.9$ & $85.7-99.7$ & \\
\hline USA & $30 / 57$ & $\lg A / \lg G$ & $3-4 d<$ & $96.66 / 100$ & $92.98 / 98.24$ & [38] \\
\hline
\end{tabular}

Table 3: Performance of LFIA serological test in different countries.

\begin{tabular}{|c|c|c|c|c|c|c|}
\hline Country & $\begin{array}{l}\text { COVID-19 } \\
\text { cases/ } \\
\text { nonCOVID-19 } \\
\text { cases }\end{array}$ & Antibodies & $\begin{array}{l}\text { Days from } \\
\text { disease } \\
\text { onset }\end{array}$ & Sensitivity \% & Specificity \% & Reference \\
\hline China & $397 / 128$ & $\lg G / \lg M$ & - & 88.66 & 90.6 & [46] \\
\hline \multirow[t]{3}{*}{ China } & $90 / 89$ & $\lg G / \lg M$ & $0-7 d$ & 18.8 & 77.8 & [10] \\
\hline & & & $8-15 d$ & 100 & 50 & \\
\hline & & & $16 \mathrm{~d}<$ & 100 & 64.3 & \\
\hline \multirow[t]{3}{*}{ China } & 38 & $\lg M / \lg G$ & $0-7 d$ & $23 / 53$ & -- & [6] \\
\hline & & & $8-14 d$ & $50 / 87.5$ & & \\
\hline & & & $15 d<$ & $52.2 / 91.3$ & & \\
\hline \multirow[t]{2}{*}{ China } & $91 / 35$ & $\operatorname{lgM} / \lg G$ & -- & $57.1 / 81.3$ & 100 & [32] \\
\hline & & $\lg G+\lg M$ & & 82.4 & & \\
\hline \multirow[t]{2}{*}{ China } & 41 & $\lg M / \lg G$ & 2 weeks & 29.3/46.3 & -- & [47] \\
\hline & & $\lg G+\lg M$ & & 63.4 & & \\
\hline \multirow[t]{3}{*}{ China } & 86 & $\lg M / \lg G$ & $1-7 d$ & 11.1 & -- & [42] \\
\hline & & & $8-14 d$ & 92.2 & & \\
\hline & & & $15 d<$ & 96.8 & & \\
\hline
\end{tabular}




\begin{tabular}{|c|c|c|c|c|c|c|}
\hline Italy & $80 / 30$ & $\lg M / \lg G$ & median7d & 63.3 & 100 & [52] \\
\hline \multirow[t]{2}{*}{ Denmark } & $30 / 82$ & $\operatorname{lgM} / \lg G$ & $7-23 d<$ & $80-100$ & $80-100$ & [39] \\
\hline & & 6 POC & & & & \\
\hline \multirow[t]{3}{*}{ Spain } & $55 / 45$ & $\operatorname{lgM} / \lg G$ & $<7 d$ & 12.5 & 100 & [45] \\
\hline & & & $7-13 d$ & 33.3 & & \\
\hline & & & $14 d<$ & 73.9 & & \\
\hline USA & $37 / 30$ & $\operatorname{lgM} / \lg G$ & -- & 91.8 & 99.5 & [61] \\
\hline \multirow[t]{2}{*}{ UK } & $40 / 142$ & $\lg M / \lg G$ & $0-28 d$ & $55-70$ & $95-100$ & [31] \\
\hline & & 9 LFIA & & & & \\
\hline \multirow[t]{3}{*}{ Japan } & $112 / 48$ & $\operatorname{lgM} / \operatorname{lgG}$ & $<1$ week & 27.8 & 98 & [53] \\
\hline & & & $1-2$ weeks & 48 & & \\
\hline & & & 2 weeks $<$ & 95.8 & & \\
\hline \multirow[t]{2}{*}{ USA } & $11 / 108$ & $\operatorname{lgM} / \lg G$ & $20 d<$ & $81.8-100$ & $84.3-100$ & [50] \\
\hline & & 10 LFIA & & & & \\
\hline Iran & $114 / 198$ & $\operatorname{lgM} / \lg G$ & $5-53 d$ & $47.9 / 47$ & $99 / 100$ & [48] \\
\hline \multirow[t]{2}{*}{ Germany } & $10 / 13$ & $\lg M / \operatorname{lgG}$ & $5-9 d$ & 62.5 & 100 & [40] \\
\hline & & & $10-18 d$ & 93.8 & & \\
\hline \multirow[t]{2}{*}{ France } & $15 / 20$ & $\operatorname{lgM} / \operatorname{lgG}$ & $15 d<$ & 76.9-93.3 & $65-100$ & [41] \\
\hline & & $6 \mathrm{POC}$ & & & & \\
\hline \multirow[t]{2}{*}{ Germany } & $27 / 22$ & $\lg M / \lg G$ & median & 36.4 & 88.9 & [49] \\
\hline & & & $18.5 d$ & & & \\
\hline Brazil & $83 / 100$ & $\operatorname{lgM} / \lg G$ & $10 d$ & 77.1 & 98 & [43] \\
\hline
\end{tabular}

